\title{
Acute and chronic pathological effects with biochemical alteration of thyroid gland induced by $\mathrm{NaF}$ in Wistar rats
}

\author{
B. M. Jwad \\ Coll. of Vet. Med.-Univ. of Baghdad \\ email: Bassimpatho@yahoo.com
}

\begin{abstract}
Thirty Wistar albino rats of both sex, 1-1.25 months old (average body weight 250 $300 \mathrm{gm}$ ) were used. Animals were randomly divided into three groups. $1^{\text {st }}$ group (acute group) $\mathrm{n}=10$ given $0.5 \mathrm{ml}$. contain $500 \mathrm{mg} / \mathrm{kg} /$ body weight $\mathrm{NaF}$, as single toxic dose via stomach tube. $2^{\text {nd }}$ group (chronic group) $\mathrm{n}=10$ given $0.5 \mathrm{ml}$. contain $150 \mathrm{mg} / \mathrm{kg} / \mathrm{body}$ weight $\mathrm{NaF}$ via stomach tube daily for 60 days. $3^{\text {rd }}$ group (control group) $n=10$ given $0.5 \mathrm{ml}$. physiological saline via stomach tube. Clinical signs were reported during the course of the study, and then sacrificed after 3 and 7 days in $1^{\text {st }}$ group, and 30 and 60 days in $2^{\text {nd }}$ group, then post mortem examination was done, and any gross lesions were reported. Blood collected was done for biochemical examination (T3, T4, and TSH.) using special biochemical kits. Pieces of thyroid were taken, fixed in $10 \%$ formalin for 72 hours, and then all the specimens were processed and the histopathological changes were observed under light microscope. The pathological results showed hemorrhage appear in capsular region of thyroid gland with vacuolation in cytoplasm of cell of colloid with neutrophils infiltration in lumen, as well as edema with fume cytoplasm and marked vacuolation of cytoplasm of colloid cell, also granulomatous lesion seated in gland parenchyma. That causes alteration of biochemical test T3, T4 and TSH in acute and chronic toxic doses.
\end{abstract}

Key word :- Thyroid gland, NaF , fluoride, ( T3,T4\&TSH) hormone.

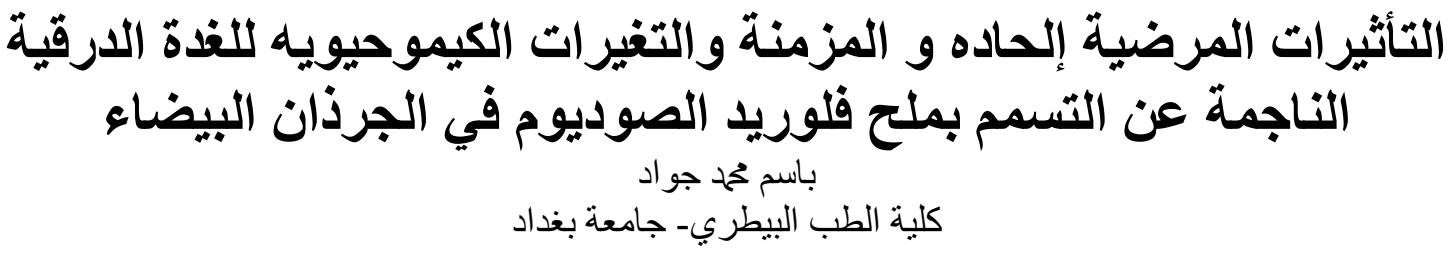

\footnotetext{
الخلاصة

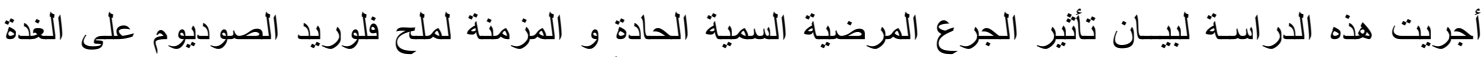

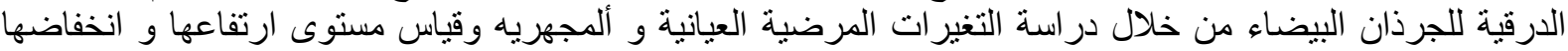

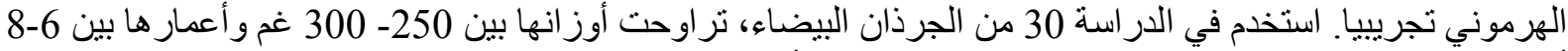

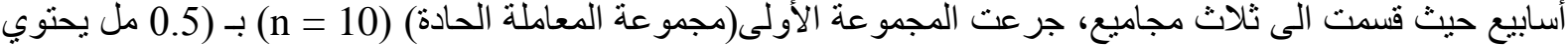

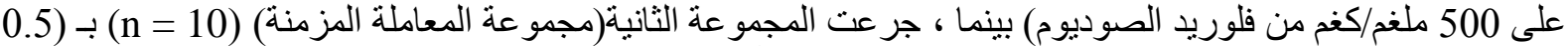

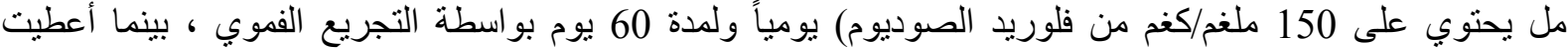

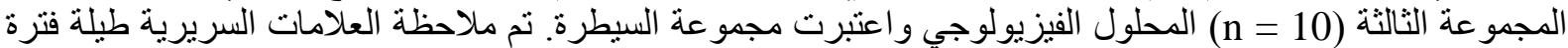

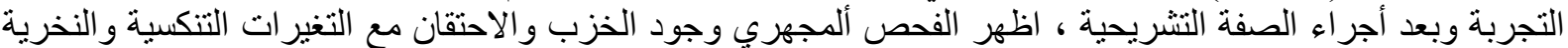

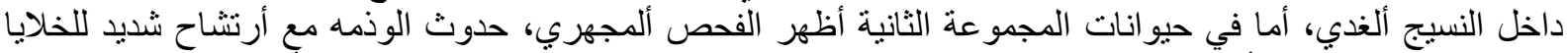

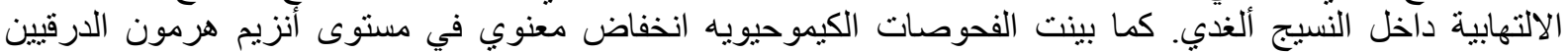

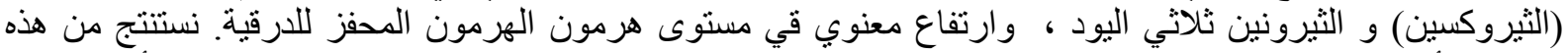

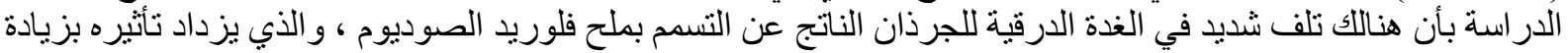

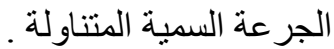
الكلمات المفتاحية: الغدة الدرقية ، كلوريد الصوديوم ، الجرذان البيضاء
} 


\section{Introduction}

Some years ago fluoride compounds were used to treat hyperthyroidism and depress thyroid function, and numerous studies on the effects of fluoride on thyroid function have been conducted on humans, cattle, calves and adult rats (1).Various factors such as iodine deficiency, dietary goitrigens, malnutrition, heredity, ionizing radiation, and pollution can induce non-toxic goiter (2). Although there is evidence to the contrary, it is generally believed that fluorine as used to prevent dental caries at the level of $1 \mathrm{ppm}$ F- in drinking water does not affect either thyroid function or its structure (3).The $\mathrm{NaF}$ causes mutagenic effects, characterizes by chromosomal aberration and micronuclei, with pathological changes in parenchymatous organs characterized by necrosis, granulomatous lesion and depletion of lymphoid follicles, in male mice during indirect intake of fluoride by drinking water (4).On the other hand, if fluorine intake is extremely high as in an endemic fluorosis area, several parameters of thyroid activity are reported to be disturbed (5). The thyroid gland appears to be the most sensitive tissue in the body to F-, which is able to increase the concentration of thyroid stimulating hormone (TSH) and decrease the concentration of $\mathrm{T} 3$ and $\mathrm{T} 4$ hormones, thereby producing hypothyroidism in some populations (6).So the goal of the present study are to determine the influence of acute and chronic toxic doses of $\mathrm{Naf}$ on pathological and biochemical alteration of thyroid gland .The aim of the present study are to determine the influence of different dose of sodium fluoride $(\mathrm{NaF})$ on the pathological and biochemical alteration on thyroid gland at acute and chronic effects in Wister albino rats.

\section{Materials and methods}

Chemicals used in this study are of the highest available purity. sodium fluoride (99.99\% NaF). Supplier from Riedel Dehaën Germen.

Models : Thirty Wistar albino rats, both sex about 1-1.25 months old (average Body weight $250-300 \mathrm{gm}$ ), these animals were housed in the animal house of department of pathology/ Collage of Veterinary Medicine /Baghdad University in a room $6 \mathrm{X} 4 \mathrm{X} 3 \mathrm{~m}^{3}$

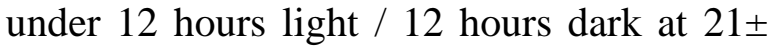
$4 C^{\circ}$. The animals were given pelleted rat diet and water.

Experimental design: animals were randomly divided into three group. $1^{\text {st }}$ group (acute group) $\mathrm{n}=10$ give $0.5 \mathrm{ml}$. contain 500 $\mathrm{mg} / \mathrm{kg} / \mathrm{body}$ weight $\mathrm{NaF}$, as single toxic dose, via stomach tube. $2^{\text {nd }}$ group (chronic group) $\mathrm{n}=10$ give $0.5 \mathrm{ml}$. contain 150 $\mathrm{mg} / \mathrm{kg} / \mathrm{body}$ weight $\mathrm{NaF}$, dose, via stomach tube daily for 40 days. $3^{\text {rd }}$ group (control group) $\mathrm{n}=10$ give $0.5 \mathrm{ml}$. mammalian physiological saline via stomach tube. During the course of study, any clinical signs were reported, all animal were sacrificed after 3 and 7 days in $1^{\text {st }}$ group, and 30 and 60 days in $2^{\text {nd }}$ group, than post mortem examination was done for blood collected and any gross lesions were reported. Thyroid gland was taken for fixed in 10\% formalin for 72 hours, and processed according to (7) and the histopathological changes were observed under light microscope.

\section{Biochemical kit :-}

Measurement of trioiodothyronine (T3), thyroxin (T4) and thyroid stimulating hormone (TSH). trioiodothyronine (T3), thyroxin (T4) and thyroid stimulating hormone (TSH) were determined by using Radioimmunoassay (RIA) in Radio Active Isotope Clinical Laboratory/ Baghdad Harthia. Principle the Assay of $\mathrm{T} 3$ and $\mathrm{T} 4$ : The radioimmunoassay of total $\mathrm{T} 3$ and total T4 is a competition assay, samples and calibrators are incubated with ${ }^{125} \mathrm{I}$ - labeled T3 and ${ }^{125} \mathrm{I}$ - labeled T4 respectively, as a tracer, in antibody - coated tubes, After in incubation, the liquid content of tubes is aspirated and the bound radioactivity, is determined in a gamma counter, the T3 and T4 concentrations in the samples are obtained by interpolation from the standard curve. Reagent provided: Kits for determination of total $\mathrm{T} 3$ and total $\mathrm{T} 4$ which composed from :-

1-Anti-T3 and Anti-T4 monoclonal antibody coated tubes. 


2- ${ }^{125} \mathrm{I}-$ labeled T3 and ${ }^{125} \mathrm{I}$ - labeled T4
tracers.

3-Calibrators Control serum vials (lyophilized) Results are obtained from the standard curve by interpolation. The curve serves for the determination of total $\mathrm{T} 3$ and total $\mathrm{T} 4$ concentrations in samples measured at the same time as the calibrators.

Principle assay of Thyroid stimulating hormone(TSH):-

The immunoradiometric assay of TSH is $\mathrm{a}^{*}$ sandwich* type assay. Mouse monoclonal antibodies direct against two different epitopes of TSH and hence not competing are used. The samples are incubated in tubes coated with first monoclonal antibody in the presence of second monoclonal antibody labeled with iodine 125 . After incubation, the content of tubes is aspirated and the tubes are rinsed so as to remove unbound ${ }^{125}$ I-labeled antibody. The bound radioactivity is then determined in a gamma counter, the TSH concentrations in the samples are obtained by interpolation from the standard curve, the concentration of TSH in the samples is directly proportional to the radioactivity.

Reagent provided:- Kit for determination of TSH which composed from:-

a- Anti-TSH antibody - coated tubes

b- ${ }^{125}$ I-labeled monoclonal anti-TSH

antibody.

c- Calibrators

d- Control serum (lyophilized)

e- Wash solution Results are obtained from the standard curve by interpolation. The curve serves for the determination of TSH concentrations in samples measured at the same time as the calibrators.

Statistical analysis:- Factorial experiment applied in completely randomized design (CRD) was used to study the effect of treatment and month in different trails. Least significant difference (L.S.D) was used to compare the significant difference between means .Data were analyzed using statistical analysis system (SAS 2002) program .

\section{Results}

\section{1-Biochemical test :-}

In acute(500 mg NaF/k.w):-

Serum triiodothyronine concentration (T3)

$(\mathbf{n g} / \mathbf{m l}):$-There are no significant increase in values of control and acute toxic group at zero days $(1.04 \pm 0.060 ; 1.01 \pm 0.050)$ respectively. The results of $\mathrm{T} 3$ appear in (table:1) show significant decreased $(\mathrm{P} \leq 0.01)$ in acute toxic groups through three and seven days when compared with control $(0.05 \pm$ $0.005 ; 0.07 \pm 0.005),(1.01 \pm 0.052 ; 1.00 \pm$ $0.052)$ respectively. Also there is no significant evaluation at $(\mathrm{P} \leq 0.01)$ between the values of three and seven days $(0.05 \pm$ $0.005 ; 0.07 \pm 0.005)$ respectively, during period of this study.

Table (1): Effect of Serum Triiodothyronine concentration (T3) $(\mathrm{ng} / \mathrm{ml})$ in rats after administration $500 \mathrm{mg}$ NaF/k.w orally.

\begin{tabular}{|c|c|c|}
\hline Day Groups & $\mathrm{C}$ & Acute \\
\hline \multirow[t]{2}{*}{ Zero } & $1.04 \pm 0.060$ & $1.01 \pm 0.050$ \\
\hline & $\mathrm{A} \quad \mathrm{a}$ & $\mathrm{A} \quad \mathrm{a}$ \\
\hline \multirow[t]{2}{*}{3} & $\begin{array}{l}1.01 \pm \\
0.052\end{array}$ & $0.05 \pm 0.005$ \\
\hline & A a & B \\
\hline \multirow[t]{2}{*}{7} & $1.00 \pm 0.052$ & $0.07 \pm 0.005$ \\
\hline & $\mathrm{A} \quad \mathrm{a}$ & B $\quad$ b \\
\hline L.S.D & \multicolumn{2}{|c|}{1.36} \\
\hline
\end{tabular}

Values are presented as means \pm SE. $(n=5$ rats /group $)$. Different small letters means significant $(\mathrm{P} \leq 0.01)$ results between days. Different capital letters means significant $(\mathrm{P} \leq 0.01)$ results between groups.

\section{Serum thyroxine concentration(T4)} $(\boldsymbol{u g} / \mathbf{d l})$ :- There are no significant increase in values of control and acute toxic group at zero days $(1.00 \pm 0.070 ; 1.02 \pm 0.070)$ respectively. The results of $\mathrm{T} 4$ appear in (table:2) show significant decreased $(\mathrm{P} \leq 0.01$ ) in acute toxic groups during three and seven days when compared with control $(0.02 \pm$ $0.003 ; 0.03 \pm 0.002),(1.03 \pm 0.070 ; 1.05 \pm$ $0.070)$ respectively. Furthermore there is no significant variation at $(\mathrm{P} \leq 0.01)$ between the values of three and seven days $(0.02 \pm$ $0.003),(0.03 \pm 0.002)$ respectively, at period of study. 
Table (2): Effect of Serum thyroxin concentration (T4) (ug/dl) in rats after administration $500 \mathrm{mg} \mathrm{NaF/k.w}$ orally.

\begin{tabular}{|c|c|c|}
\hline Day Groups & $\mathrm{C}$ & Acute \\
\hline \multirow[t]{2}{*}{ Zero } & $1.00 \pm 0.07$ & $1.02 \pm 0.07$ \\
\hline & A $\quad$ a & A $\quad$ a \\
\hline \multirow[t]{2}{*}{3} & $1.03 \pm 0.07$ & $0.02 \pm 0.03$ \\
\hline & A $\quad \mathrm{a}$ & B $\quad$ b \\
\hline \multirow[t]{2}{*}{7} & $1.05 \pm 0.07$ & $0.03 \pm 0.02$ \\
\hline & A $\quad$ a & B \\
\hline L.S.D & \multicolumn{2}{|c|}{1.14} \\
\hline
\end{tabular}

Values are presented as means \pm SE. ( $n=5$ rats /group). Different small letters means significant $(\mathrm{P} \leq 0.01)$ results between days. Different capital letters means significant $(\mathrm{P} \leq 0.01)$ results between groups.

\section{Serum Thyroid stimulating hormone} concentration (TSH) (mU/L) :-

There are no significant increase in values of control and acute toxic group at zero days $(0.48 \pm 0.05 ; 0.44 \pm 0.05)$ respectively. The results of TSH. appear in (table:3), show significant increased $(\mathrm{P} \leq 0.05)$ in acute toxic groups during three and seven days when compared with control $(1.07 \pm 0.07 ; 1.09 \pm$ $0.08), 0.56 \pm 0.06 ; 0.50 \pm 0.06)$ respectively. in addition there is no significant variation at $(\mathrm{P} \leq 0.05)$ between the values of three and seven days $(1.07 \pm 0.07)$, ( $1.09 \pm 0.08)$ respectively, through period of study.

Table (3): Effect of Serum Thyroid stimulating hormone $(\mathrm{TSH})(\mathrm{mU} / \mathrm{L})$ in rats after administration $500 \mathrm{mg} \mathrm{NaF} / \mathrm{k} . \mathrm{w}$ orally.

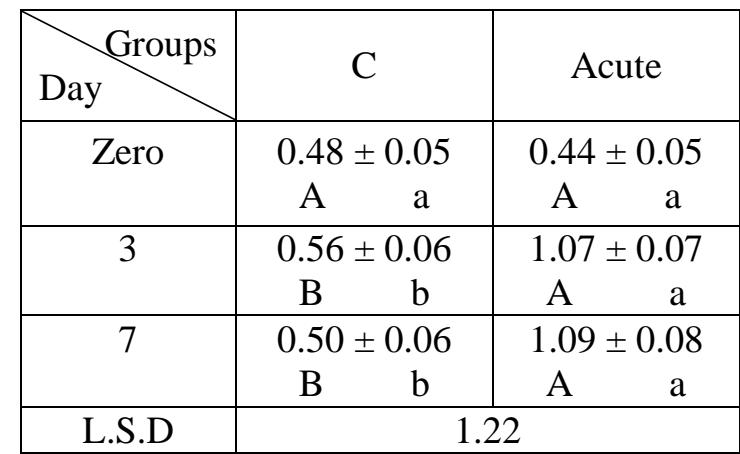

Values are presented as means \pm SE. ( $n=5$ rats /group). Different small letters means significant $(\mathrm{P} \leq 0.05)$ results between days. Different capital letters means significant $(\mathrm{P} \leq 0.05)$ results between groups.
(B)In chronic (150 mg NaF/ k.w):-

Serum triiodothyronine concentration (T3) (ng/ml) :-

There are no significant increase in values of control and acute toxic group at zero days $(1.00 \pm 0.061 ; 1.00 \pm 0.061)$ respectively. The results of $\mathrm{T} 3$ appear in (table:4) show significant decreased $(\mathrm{P} \leq 0.01$ ) in acute toxic groups through 30 and 60 days when compared with control $(0.04 \pm$ $0.003 ; 0.02 \pm 0.003),(1.05 \pm 0.050 ; 1.00 \pm$ $0.050)$ respectively. Also there is significant increase at $(\mathrm{P} \leq 0.01)$ between the values of 30 and 60 days $(0.04 \pm 0.003) ;(0.02 \pm$ 0.003 ) respectively, during period of this study.

Table (4): Effect of Serum Tri-iodothyronine concentration (T3) $(\mathrm{ng} / \mathrm{ml})$ in rats after administration $150 \mathrm{mg} \mathrm{NaF/k.w}$ orally.

\begin{tabular}{|c|c|c|}
\hline $\begin{array}{l}\text { Groups } \\
\text { Day }\end{array}$ & $\mathrm{C}$ & Chronic \\
\hline \multirow[t]{2}{*}{ Zero } & $1.00 \pm 0.061$ & $1.00 \pm 0.060$ \\
\hline & $\mathrm{A} \quad \mathrm{a}$ & $\mathrm{A} \quad \mathrm{a}$ \\
\hline \multirow[t]{2}{*}{30} & $1.05 \pm 0.050$ & $0.04 \pm 0.003$ \\
\hline & A a & $\mathrm{B} \quad \mathrm{b}$ \\
\hline \multirow[t]{2}{*}{60} & $1.06 \pm 0.050$ & $0.02 \pm 0.003$ \\
\hline & $\mathrm{A} \quad \mathrm{a}$ & B $\quad$ b \\
\hline L.S.D & \multicolumn{2}{|c|}{1.11} \\
\hline
\end{tabular}

Values are presented as means \pm SE. ( $n=5$ rats /group). Different small letters means significant $(\mathrm{P} \leq 0.01)$ results between days. Different capital letters means significant $(\mathrm{P} \leq 0.01)$ results between groups.

\section{Serum thyroxine concentration (ug/dl):-}

There are no significant increase in values of control and acute toxic group at zero days $(1.02 \pm 0.08 ; 1.03 \pm 0.08)$ respectively. The results of $\mathrm{T} 4$ appear in (table:5) show significant decreased $(\mathrm{P} \leq 0.01$ ) in acute toxic groups during 30 and 60 days when compared with control $(0.03 \pm 0.003$; $0.01 \pm 0.002),(1.01 \pm 0.08 ; 1.00 \pm 0.08)$ respectively. Furthermore there is significant decrease at $(\mathrm{P} \leq 0.01)$ between the values of 30 and 60 days $(0.03 \pm 0.003),(0.01 \pm 0.002)$ respectively, at period of study. 
Table (5): Effect of Serum thyroxin concentration (T4) (ug/dl) in rats after administration $150 \mathrm{mg} \mathrm{NaF/k.w}$ orally.

\begin{tabular}{|c|c|c|}
\hline Day & $\mathrm{C}$ & Chronic \\
\hline \multirow[t]{2}{*}{ Zero } & $1.02 \pm 0.08$ & $1.03 \pm 0.08$ \\
\hline & $\mathrm{A} \quad \mathrm{a}$ & $\mathrm{A} \quad \mathrm{a}$ \\
\hline \multirow[t]{2}{*}{30} & $1.01 \pm 0.08$ & $0.03 \pm 0.003$ \\
\hline & $\mathrm{A} \quad \mathrm{a}$ & B $\quad b$ \\
\hline \multirow[t]{2}{*}{60} & $1.00 \pm 0.08$ & $0.01 \pm 0.002$ \\
\hline & A & B \\
\hline L.S.D & \multicolumn{2}{|c|}{1.10} \\
\hline
\end{tabular}

Values are presented as means \pm SE. ( $n=5$ rats /group). Different small letters means significant $(\mathrm{P} \leq 0.01)$ results between days. Different capital letters means significant $(\mathrm{P} \leq 0.01)$ results between groups.

\section{Serum Thyroid stimulating hormone concentration (TSH) (mU/L) :-}

There are no significant increase in values of control and acute toxic group at zero days $(0.56 \pm 0.04 ; 0.55 \pm 0.04)$ respectively. The results of TSH. appear in (table:6), show significant increased $(\mathrm{P} \leq 0.05$ ) in acute toxic groups during 30 and 60 days when compared with control $(2.32 \pm 0.41$; $4.04 \pm 0.60),(0.54 \pm 0.04 ; 0.55 \pm 0.04)$ respectively. in addition there is significant decrease at $(\mathrm{P} \leq 0.05)$ between the values of 30 and 60 days $(2.32 \pm 0.41),(4.04 \pm 0.60)$ respectively, through period of study.

\section{Pathological lesion :-}

In acute case, histopathological picture in three days showed sever hemorrhage appear in capsular region of thyroid gland, with vacuolation in cytoplasm of cell of colloid (Fig. 1). In other section sever congestion of blood vessels, with neutrophils infiltration in lumen, as well as edema which appear in the interstitial tissue of their gland (Fig. 2).
Table (6): Effect of Serum Thyroid stimulating hormone (TSH) $(\mathrm{mU} / \mathrm{L})$ in rats after administration $150 \mathrm{mg} \mathrm{NaF} / \mathrm{k} . w$ orally.

\begin{tabular}{|c|c|c|}
\hline Day & $\mathrm{C}$ & Chronic \\
\hline \multirow[t]{2}{*}{ Zero } & $0.56 \pm 0.04$ & $0.55 \pm 0.04$ \\
\hline & A $\quad \mathrm{a}$ & $\mathrm{A} \quad \mathrm{a}$ \\
\hline \multirow[t]{2}{*}{30} & $0.54 \pm 0.04$ & $2.32 \pm 0.41$ \\
\hline & B $\quad$ b & A $\quad \mathrm{a}$ \\
\hline \multirow[t]{2}{*}{60} & $0.55 \pm 0.04$ & $4.04 \pm 0.60$ \\
\hline & B $\quad$ b & A $\quad$ a \\
\hline L.S.D & \multicolumn{2}{|c|}{1.96} \\
\hline
\end{tabular}

Values are presented as means \pm SE. ( $n=5$ rats /group). Different small letters means significant $(\mathrm{P} \leq 0.05)$ results between days. Different capital letters means significant $(\mathrm{P} \leq 0.05)$ results between groups.

In seven days lesion characterizes by present fume cytoplasm of the cell colloid and marked vacuolation of cytoplasm were recorded (Fig.3).Also sever necrosis of epithelial cell lining of glandular acini that appear in all section of thyroid gland at this period (Fig. 4).In chronic, the pathological lesion at 30 days characterizes by hard sever degeneration with sever necrosis of epithelial cell lining of glandular acini (Fig.5), with esinophelic rounded droplet in the cytoplasm of necrotic cell (Fig. 6), in additional proliferation of fibrous connective tissue infiltrated with mono nuclear cells were seen in the around necrotic acini. (Fig.7). During the 60 days, the main lesion in this animal sever necrosis of aciner gland with of macrophages and Neutrophils infiltration, and congestion of blood vessels (Fig.8). Also inflammatory cell in RBC replacement the necrotic acini which appear in (Fig.9). In additional granulomatous lesion that consist from aggregation of macrophage seated in gland parenchyma, in addition to fibrous connective tissue proliferation (Fig.10). In other section neutrophil depressed in lumen of glandular tissue, as well as vacuolation in cytoplasm of the aciner cells (Fig.11). 

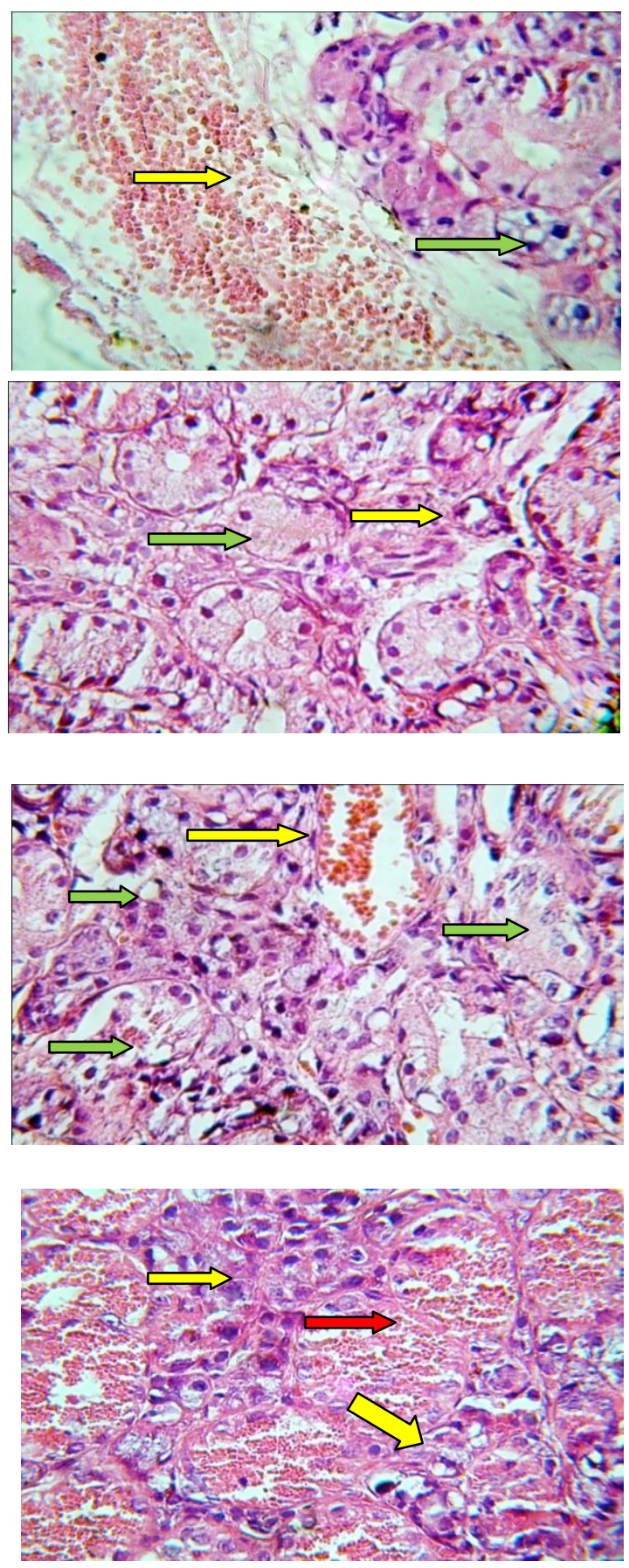

Fig.1: Histopathological section in thyroid gland of rat in acute at 3day show severe hemorrhage appear in capsular region of thyroid gland, with vacuolation in cytoplasm of cell of colloid $\Rightarrow$

Fig.2: Histopathological section in thyroid gland of rat in acute at 3day show neutrophils infiltration in lumen $\Rightarrow$, as well as edema which appear in the interstitial tissue of thyroid gland $\Longrightarrow$

Fig.3: Histopathological section in thyroid rat in acute at 7day show foamy cytoplasm of the cell colloid and marked vacuolation of cytoplasm were recorded $\Longrightarrow$ also there is severe congestion $\Longrightarrow$

Fig.4: Histopathological section in thyroid rat in acute at 7day show severe necrosis of epithelial cell lining of glandular acinia that appear in all section of thyroid gland at this period $\Rightarrow$ and severe hemorrhage 

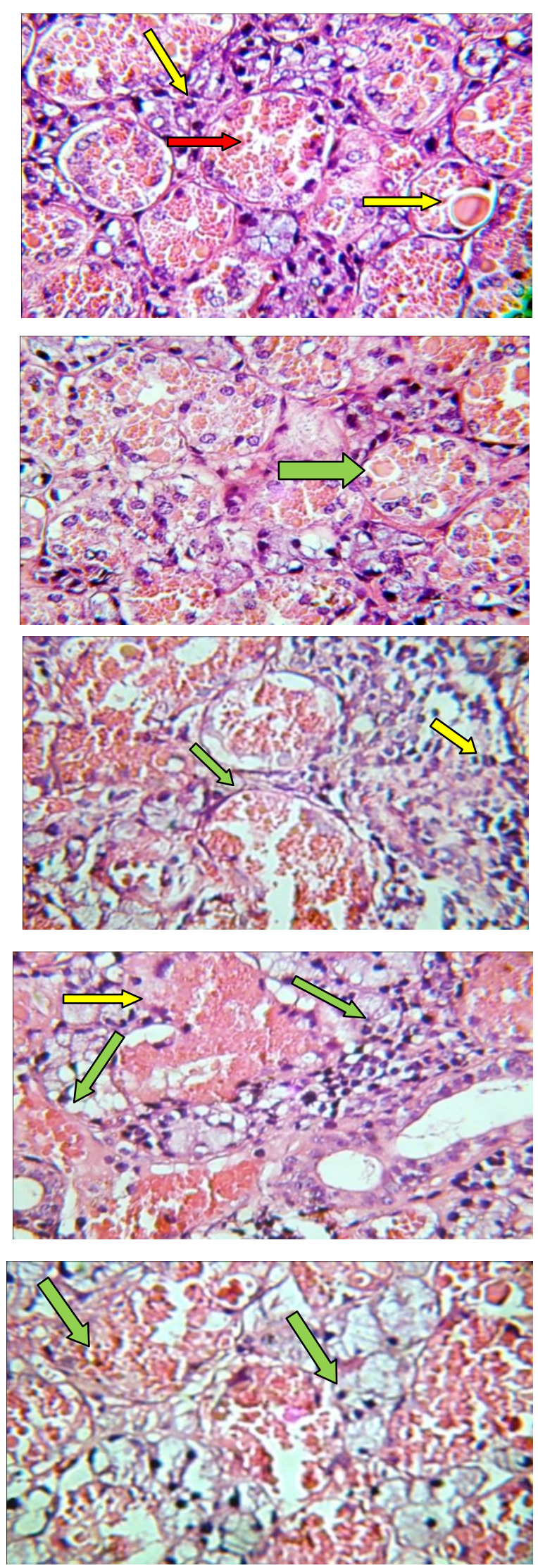

Fig.5: Histopathological section in thyroid gland of rat in chronic at 30 day show necrosis with esinophelic rounded droplet in the cytoplasm of necrotic cell $\Longrightarrow$ With hemorrhage $\rightarrow$

Fig.6: Histopathological section in thyroid gland of rat in chronic at 30 day show eosinophelic rounded droplet in the cytoplasm of necrotic cell $\Rightarrow$

Fig.7: Histopathological section in thyroid gland of rat in chronic at 30 day show proliferation of fibrous connective tissue $\Rightarrow$ infiltrated with mono nuclear cells were seen in the necrotic acinia $\Longrightarrow$

Fig.8: Histopathological section in thyroid gland of rat in chronic at 60 day show severe necrosis of acinar gland $\Rightarrow$ with of macrophages and neutrophils infiltration, and congestion of blood vessels $\Rightarrow$

Fig.9: Histopathological section in thyroid gland of rat in chronic at 60 day show inflammatory cell and RBC replacement the necrotic acina $\Rightarrow$ 

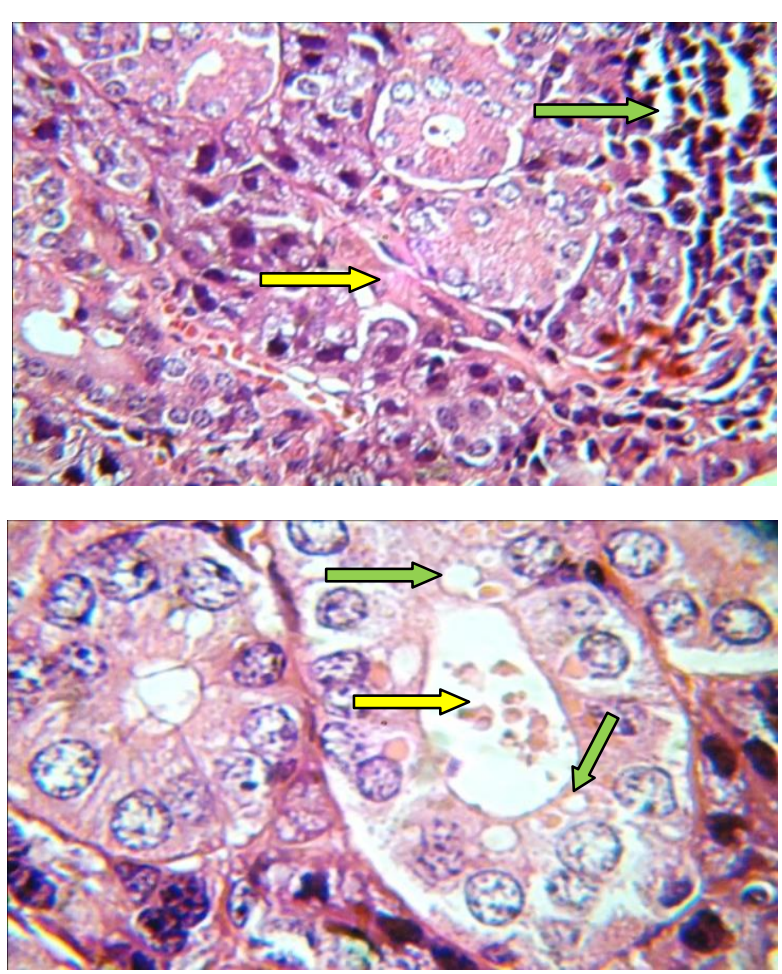

\section{Discussion}

The biochemical alteration of thyroid hormone through decreased the level of (T3and T4) with increase of (TSH), at acute and chronic effect of sodium fluoride, may occur because massive degeneration with severe necrosis of acinar gland which causes, combination aluminum with fluoride ion that result (AlFx) mimics normal phosphate (8). Also interaction that occur between fluoride and iodine resulting in a functional iodine deficiency, lead to reduced tissue iodine levels, all these effects of $\mathrm{NaF}$ causes changes of thyroid metabolism function, lead to decrease in T3 and T4, lead to stimulation of hypothalamus increase in TSH hormone (9).This result agree with (10) who reported that effected of thyroid function in suckling and adult female mice when gives (500 ppm $\mathrm{NaF}$ ) in their drinking water from the 15th day of pregnancy until either the 4th or 14th day after parturition. Also the results were in agreement with (11) who investigated that the increasing fluoride in the diet, the serum TSH level was increased in rats. The results differed with (12) who reported that subsequent elevation in serum $\mathrm{T} 3$ and $\mathrm{T} 4$ concentration of young pig when intake sodium fluoride.Histopathological results
Fig.10: Histopathological section in thyroid gland of rat in chronic at 60 day show granulomatous lesion that consist from aggregation of macrophage seated in gland parenchyma $\Longrightarrow$ in addition to fibrous connective tissue proliferation. $\Longrightarrow$

Fig.11: Histopathological section in thyroid gland of rat in chronic at 60 day show section cellular depressed in lumen of glandular tissue $\Longrightarrow$ as well as vacuolation in cytoplasm of the aciner cells $\Longrightarrow$ showed severe damage and destruction in gland tissue parenchyma, with hemorrhage and vacuolation in cytoplasm of cell of colloid gland this occur may be due to severe inflammation that present in thyroid gland, lead to vasodilatation and vasoconstriction which causes damage or congestion of blood vessels, causes oozing of blood and fluid "edema" with infiltration of mono nuclear cells "MNCs". This evidence was in consistence with (13) who predicted that fluoride causes morphological structure in thyroids tissue of rats, after administered 50,100 and $200 \mathrm{mg} / \mathrm{L}$ of $\mathrm{NaF}$ in drinking water, for 150 days. In 60 days, present of fibrous connective tissue infiltrated with polymorphic nuclear cells "PNCs" were seen in the necrotic acinia with granulomatous lesion. These occur because severe excessive effects of $\mathrm{NaF}$ which causes disturbance of thyroid hormone (T3, T4 and TSH) that lead to activating a calcium - transuding G-protein receptor $G \mathrm{q} / 11$, that induce increased in the oxygen radical generation and lipid peroxidation in the pathogenesis of fluoridated water and these will cause destruction in the cellular membrane by simple diffusion it's enter in cell and damage cell, and aggregation of PNCs specially 
macrophages in tissue (14 and 15). This evidence was in consistence with (6) who predicted that give rabbit $100 \mathrm{ppm} \mathrm{NaF}$ in drinking water causes irregular colloid substances with vacuolation, together with hyperplasia of epithelial lining cells of acenid. Also the result similar with (16) who investigated that gives rats diet and high $\mathrm{F}$ (338 mg NaF[ $=150 \mathrm{mg} \mathrm{F}$ ion $] / \mathrm{L}$ in drinking water, demonstrated flatted follicular epithelia cells and hyperplastic nodules, consisting of thyroid Para follicular cells.

\section{Reference}

1-Cinar A. and Selcuk M. (2005). Effects of chronic fluorosis on thyroxine, triiodothyronine, and protein-bound iodine in cows. Fluoride.38:65-8.

2-Pedraza, P.E.; Obregon, M.J.; Escobar-Morreale, H.F.; Escobar, D.; Rey, F.; Morreale, D. and Escobar, G. (2006).Mechanisms of adaptation to iodine deficiency in rats: thyroid status is tissuespecific. Its relevance for man. Endocrinology, 147: 2098-2108.

3-WHO.(2012). [( Grandjean P, Landrigan PJ. Developmental neurotoxicity of industrial chemicals. Lancet)] by. www.WHO.org. June. 29.2012.

4- Jwad B. M.(2010). Toxicopathological and Mutagenic effects of fluoride given in drinking water to male mice. MS.c thesis, Department of Pathology. College of Veterinary Medicine, University of Baghdad. Baghdad, Iraq.

5-Durrant-Peatfield B. The effects of fluoride on the thyroid gland. Available from: http://rense.com/general57/FLUR.HTM.

6-Awse Muhammed Ali, Aldabaj.(2010). Effect of grape seed oil on hepatic, thyroid and adrenal functions in adult male rabbits treated with sodium fluoride. MS.c thesis, Department of Physiology. College of Veterinary Medicine, University of Baghdad. Baghdad, Iraq.

7- Lee, G. and Luna, L.G. (1968). Manual of histological staining methods of Armed Forces institutes of pathology. 3rded. Mc Grow-Hill Book Company. New York. Pp: 12-31.

8-Thomas, C.; Auwerx, J. and Schoonjans, K. (2008). Bile acids and the membrane bile acid receptor TGR5 connecting nutrition and metabolism. Thyroid, 18(2): 167-74.

9-Carole Clinch.(2009). Fluoride interaction with iodine and iodide "IMPLICATIONS FOR

\section{Conclusion}

The present study investigated that the sodium fluoride affected on the thyroid gland by, histopathological alteration in tissue during toxicopathological effects at acute and chronic toxic doses, that cause abnormal changes of thyroid metabolism function in biochemical parameters through decreased in blood thyroxin (T4) and tri-iodothyronine (T3) with increased of plasma thyroid stimulating hormone (TSH). And the degree of influence depended on the concentration of the toxic dose .

BREAST HEALTH". Avenue, Waterloo, Ontario. Canada. Fluoride 42(2)75-87.

10-Hanen Bouaziz ; Lotfi Soussia ; Fadhel Guermazi and Najiba Zeghal. (2005). Fluoride induced thyroid proliferation changes and their reversal in female mice and their pups. Animal Physiology Laboratory, Sciences Life Department. Nuclear Medicine Service, CHU, Sfax, Tunisia. Fluoride.38(3):185-192.

11- Xiang, Q.; Chen, L.; Liang, Y.; Wu, M. and Chen, B. (2009).Fluoride and thyroid function in children in two villages in China. J. Toxicol. Environ. Health Sci., 1(3): 54-59.

12-Xiuan, Z.; Jianxin, L.; Min, W. and Zirong, X. (2006).Effects of fluoride on growth and thyroid function in young pigs. Fluoride, 39(2): 95-100.

13-Liu, G.; Zhang, W.; Gu, J. and Chai, C. (2008).Effects of Fluoride on Morphological Structure and Function of Thyroids in Rats. J. Shanghai Jiaotong University. Agric. Sci., 26(6): 537-539.

14-Khalid Nassif Jassim. (2011). The comparison study of Fluoride kinetics in saliva after the use of chewing gums containing different fluoride compounds in Iraqi subjects. College of Dentistry, University of Al-Mustansiryia. Baghdad, Iraq. AJPS, Vol. 10, No.2.

15- Stepniak, I. and Czarnowski, W. (2010).Oxidative stress parameters in rats exposed to fluoride and caffeine. Food Chem. Toxicol., 48: 1607-1611.

16-Wang, H.; Yang, Z.; Zhou, B.; Gao, H.; Yang, X. and Wang, J. (2009).Fluoride induced thyroid dysfunction in rats: roles of dietary protein and calcium level. Toxicol. Industrial Health, 25: 4957. 